\title{
Microtubule-Associated Protein 4
}

National Cancer Institute

\section{Source}

National Cancer Institute. Microtubule-Associated Protein 4. NCI Thesaurus. Code C104638.

Microtubule-associated protein $4(1152 \mathrm{aa}, \sim 121 \mathrm{kDa})$ is encoded by the human MAP4 gene. This protein plays a role in both microtubule assembly and cell cycle progression. 